\title{
建物の断熱性能と暖房方式が室内温熱環境と室内投入熱量に与える影響 INFLUENCE OF BUILDING INSULATION PERFORMANCE AND HEATING SYSTEMS ON THERMAL ENVIRONMENT AND ENERGY PERFORMANCE
}

\author{
大森敏明*, 田辺新一**, 板垣雅治*** \\ Toshiaki OMORI, Shin-ichi TANABE and Masaharu ITAGAKI
}

\begin{abstract}
Thermal comfort in a heated room is much affected by the characteristics of envelop, especially its thermal insulation properties and the heating system. Coupled convection-radiation simulation is conducted to estimate heat release from a floor heating system or a wall-mounted air-conditioning unit under the same equivalent temperature with simulated human body under five building insulation levels including three levels of Japanese energy conservation standards for residential building. A human body model is placed on the floor in a seated posture and controlled by comfort regulation of thermal manikin. In computations, sensible heat release from the human body is matched for different heating systems by properly controlling temperature of the heating panels under the floor or hot air from the air-conditioner. When heat loss from the bottom of the heating panels is neglected, heat release from the floor heating system is smaller than that from the air-conditioning unit.
\end{abstract}

\author{
Keywords : Building Insulation Performance. Heating Energy Consumption Rate, Coupled \\ Convection-Radiation Simulation, Equivalent Temperature, Floor Heater, Air-Conditioner \\ 断熱性能, 暖房投入熱量, 対流 - 放射連成解析, 等価温度, 床暖房, エアコン
}

\section{1. はじめに}

住宅の暖房に求められる基本性能は、温熱快適性と省エネルギ 一性を同時に満たすことである。暖房時の温熱快適性と省エネル ギー性は建物の断熱性・気密性はもちろんのこと、暖房システム によっても影響を受ける。家庭用の暖房システムは放射型と対流 型に大別されるが、これらの暖房システムによって形成される温 熱環境の相異は小さくない。本研究では、床暖房と壁掛けエアコ ンに注目し、それぞれの暖房方式によって形成される室内温熱環 境の相違とともに、全身温冷感が同一とみなせる場合の室内投入 熱量の相違を明確にすることを目的とする。

これまでに、暖房機の種類によって室内に形成される温熱環境 や暖房に必要なエネルギーが異なることを報告した研究は多い 2,3$)$ しかし、暖房方式が異なれば室内に形成される温熱環境も異なる ため、暖房に必要なエネルギーを暖房方式間で比較しょうとする 場合、どのような温熱環境の評価指標を用いるかが問題となる。 評価基準の候補としては、作用温度、PMV、SET*、等価温度な どが考えられる。

堀らは、壁・天井表面温度を空気温度とできるだけ一致させた 上で、これらの温度と床表面温度を種々に組み合わせることによ
って不均一温熱環境を形成できる人工気候室で被験者実験を行っ て、人体部位ごとの至適作用温度を導いた ${ }^{4)}$ 。至適作用温度は足 元で高く頭部で低くなるような勾配を有することを見出し、至適 作用温度と室内の人体部位における作用温度との差に基づいて全 身温泠感や不満足者率を評価できるとした。住宅事業建築主の判断 の基準におけるエネルギー消費量計算方法の解説 5)では、空気温度 と平均放射温度の算術平均值で簡易に作用温度を算出し作用温度が 一致すれば温熱環境が等価であるとみなしている。床暖房部の重み 係数を 0.4、床暖房部以外の壁体表面については各面の面積比を重 み係数として求めた平均表面温度を平均放射温度としている。しか し、作用温度は居室の速度分布に基づく対流熱伝達を含めて評価し なければならないため、暖房方式が異なる場合、このように簡易に 求めた作用温度が一致しても温熱環境が同じになるとは限らない6)

PMV は、ISO7730 7) およびASHRAE Standard 55 8)に採用さ れている代表的な温熱環境評価指標であるが、室内温熱環境が大 略均一とみなせる場合は PMV で評価して差し支えないが、不均一 な環境の評価には適さない 4)。ISO7730 では、まず熱的中立を評価 する PMV が快適範囲にあることを必要条件とし、その上で、ド ラフト・上下空気温度差・床面温度・不均一放射の局部不快感が

\footnotetext{
本論文は2008年度大会学術講演会において発表した内容 ${ }^{1)}$ を発展させてまとめたものである。

**東京ガス株) 工博 Tokyo Gas Co., Ltd., Dr. Eng.

** 早稲田大学理工学術院建築学科 教授. 工博 $\quad$ Prof., Department of Architecture, Waseda University, Dr. Eng.

*** 東京ガス(株) 工修Ｔokyo Gas Co., Ltd., M. Eng.
} 
ないことを要求している。大森らは対流 - 放射連成シミュレーシ ヨンで求めた床暖房とエアコンの温熱環境をISO7730に基づいて 評価している 9,10)。田澤らは室内温熱環境と暖房に必要なエネルギ 一の両者を人工気候室内に設置した試験室に暖房機器を設置して 評価する性能試験法を提案し、室内の 5 か所で空気温度、床温度、 グローブ温度および風速を測定している 11)。室内の温熱環境の不 均一性を考慮して、これらの測定值から上下温度差、水平温度差、 作用温度平均值、 $\mathrm{PMV}$ 平均值を算出し、温熱環境の評価指標とし ては PMV 平均值を用いている。

坂口らは、日本建築学会標準モデルの居間を対象として床暖房、 エアコンをそれぞれ用いた場合の CFD 解析を次世代省エネルギ 一基準（III地域）について実施している ${ }^{12}$ 。 温熱環境の評価指標 としては $\mathrm{SET}^{*}$ 用い床上 $0.5 \mathrm{~m}$ から $1.8 \mathrm{~m}$ までの平均值を $22^{\circ} \mathrm{C}$ と した場合、床暖房はエアコンよりも暖房に必要な熱量が $9 \%$ 多く、 断熱材厚さを半減して断熱性能を低下させたケースでは床暖房は エアコンよりも $16 \%$ 少ないという結果を示している。さらに、床 暖房とエアコンの両方を備えた次世代省エネルギー基準（IV地域） を満たす住宅を対象として居住状態において床暖房、エアコンそ れぞれが室内に放熱する熱量を 2 力月にわたる実測によって調心゙、 床暖房の方がわずかに小さい（約 $4 \%$ ）と報告している。

不均一温熱環境に PMV や SET*を用いる場合、大森ら 9,10)、田 澤ら 11)、坂口ら 12) は、それぞれ独自に設定した複数の測定点にお けるこれらの平均值と温熱環境要素の空間分布を用いて評価して おり、ISO7730 では PMV に加えて局部不快感に関する評価を求 めている。PMV および温熱環境要素の空間分布を適切に考慮すれ ば、温熱環境を評価することは可能と考えられるが、異な る居室の温熱環境が一致する条件を見出すことは容易では ない。

車室内の温熱環境評価基準である ISO14505-213)では、等 価温度を評価指標として採用し、サーマルマネキンを用い て測定された顕熱放熱量を等価温度に換算して評価するこ ととしている。等価温度を評価指標と寸る場合、人体から の顕熱放熱量が等しければ全身温冷感も等しいという前提 に立っている。サーマルマネキンを用いた等価温度は、人 体と環境との間の顕熱授受を直接評価するので、不均一な 温熱環境における全身温冷感の評価に適すると考えられる。 温熱環境が快適であるためには、全身温泠感が中立である ことが必要条件になる。従って、本研究では温熱環境等価の 条件を人体の全身温冷感が一致することとし、等価温度を温 熱環境指標として採用寸ることとした。人体モデルとしては、 コンフォート制御 14)されたサーマルマネキンの数值モデル を用い、数值サーマルマネキンからの放熱量を人体顕熱放熱 量とみなした。同一等価温度環境下においては、暖房の質と いう点から考えると、全身温冷感だけでなく局部温冷感およ びそれに付随する快適性が温熱環境を評価する上で重要な要 素である。これらを含めた暖房の質を等価に評価することが 現状では困難なため、エネルギー評価に際してはサーマルマ ネキン等価温度によるものとした。

本研究では、建物モデルの断熱性能を旧省エネルギー基準、 新省エネルギー基準、次世代省エネルギー基準、次世代省エ
ネルギー基準から一段と断熱性能を引き上げた次世代超断熱性能、 さらに壁体を断熱した完全断熱の5つの断熱レベルにそれぞれ対応 させて対流・放射連成シミュレーションを行い、人体モデルの顕熱 放熱量を代謝量 $1.1 \mathrm{met}$ 時の熱的中立状態に相当する值 $\left(44.2 \mathrm{~W} / \mathrm{m}^{2}\right)$ に保つために必要な室内暖房投入熱量を比較する。暖房システムと しては、床暖房とエアコンを取り上げた。人体姿勢は床暖房とエア コンに共通なものとして椅座位とした。これにより、人体の全身温 冷感が等価とみなせる条件下での建物断熱性能、暖房システム間の 比較が可能になる。

\section{2. 解析対象モデル}

\section{1 部屋モデル}

解析対象とした住宅の居間の概要を図 1 に示寸注 1 )。内寸法は幅 $5.33 \mathrm{~m} \times$ 奥行 $3.77 \mathrm{~m} \times$ 高さ $2.4 \mathrm{~m}$ で 13.5 畳に相当する。南側に掃き出 儿空（幅 $1.64 \mathrm{~m} \times$ 高さ $2.0 \mathrm{~m}$ ）が 2 面取り付けられ、各空にはカーテ ン（東側：幅 $1.74 \mathrm{~m} \times$ 高さ $2.05 \mathrm{~m}$ 、西側：幅 $1.69 \mathrm{~m} \times$ 高さ $2.05 \mathrm{~m}$ ) がかけられている。カーテンと空との間の距離は $50 \mathrm{~mm}$ 、カーテン の下端と床との間の距離は $15 \mathrm{~mm}$ とした。西壁の床上 $1.6 \mathrm{~m}$ に設置 された給気口と南壁に 8 個、西壁に 16 個設置された給気用シリン ダー $(18 \mathrm{~mm} \times 18 \mathrm{~mm})$ から外気が導入される。給気用シリンダーは隙 間からの漏気を模擬するために設けたものである。給気量は、給気 ロと給気用シリンダーに $50 \%$ ずつ配分した。給気は全量が北壁の床 上 $0.15 \mathrm{~m}$ に設置された排気口 $(90 \mathrm{~mm} \times 90 \mathrm{~mm})$ から排気される。 外気温度は $5.5^{\circ} \mathrm{C}$ 一定とした。建物モデルの断熱性能については、 旧省エネルギー基準、新省エネルギー基準、次世代省エネルギー基
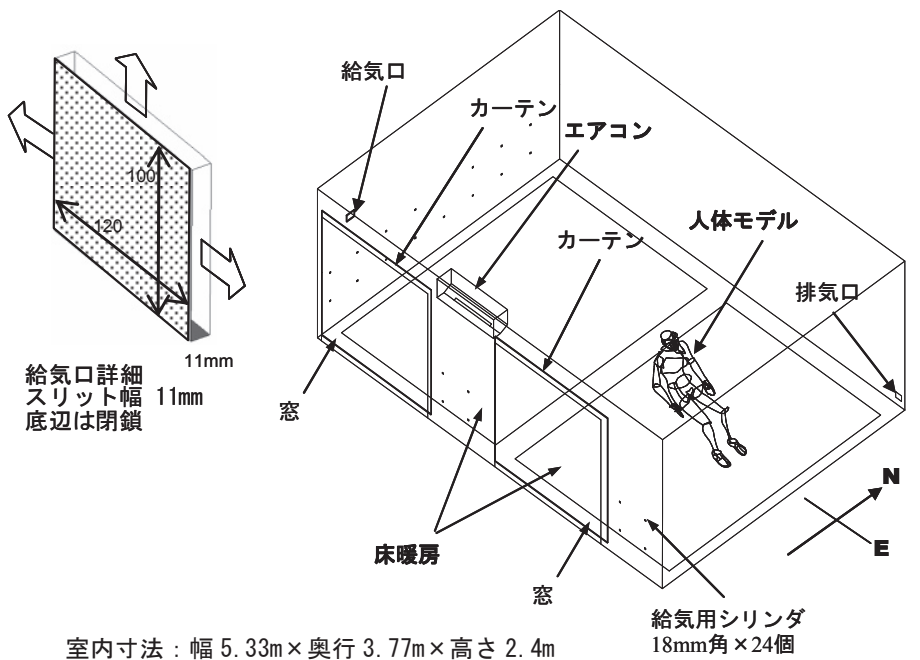

(a) 部屋モデル

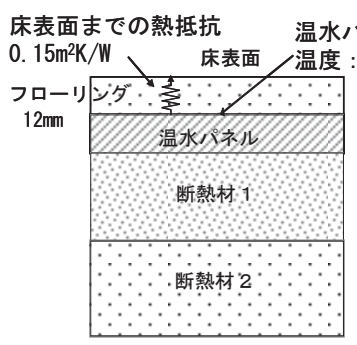

床下空気

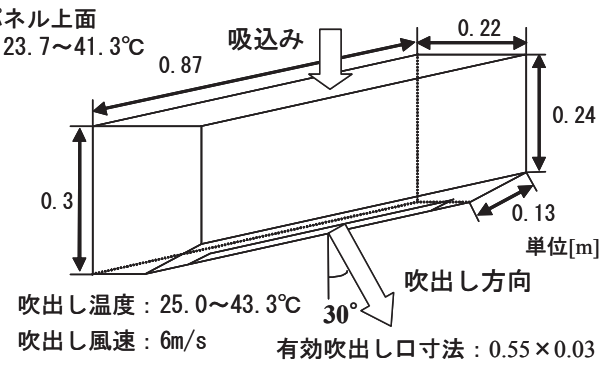

(c) エアコン吹出し部

図 1 解析対象モデル 
表 1 省エネルギー基準と断熱性能

\begin{tabular}{|c|c|c|c|c|c|c|}
\hline 項 & 目 & 旧省エネ & 新省エネ & 次世代省エネ & 次世代超 & 壁体完全断熱 \\
\hline \multicolumn{2}{|c|}{ 熱損失係数 $\left[\mathrm{W} / \mathrm{m}^{2} \mathrm{~K}\right]$} & $5.58(5.58)$ & $3.95(3.95)$ & $2.7(2.7)$ & $1.7(1.9)$ & 0.4 \\
\hline \multirow{7}{*}{$\begin{array}{l}\text { 熱貫流率 } \\
{\left[\mathrm{W} / \mathrm{m}^{2} \mathrm{~K}\right]}\end{array}$} & 北壁 & - & - & - & - & - \\
\hline & 南壁 & $1.32(1.05)$ & $0.78(0.78)$ & $0.53(0.53)$ & $0.53(0.5)$ & - \\
\hline & 西壁 & $1.32(1.05)$ & $0.78(0.78)$ & $0.53(0.53)$ & $0.53(0.5)$ & - \\
\hline & 東壁 & - & - & - & - & - \\
\hline & 床 & $1.32(1.05)$ & $0.51(0.62)$ & $0.26(0.34)$ & $0.18(0.2)$ & - \\
\hline & 天井 & - & - & - & - & - \\
\hline & 空 & $6.98(6.98)$ & $6.5(6.5)$ & $4.65(4.65)$ & $1.9(1.9)$ & - \\
\hline \multicolumn{2}{|c|}{ 換気回数 $[1 / \mathrm{h}]$} & $1.0(1.0)$ & $0.7(0.7)$ & $0.5(0.5)$ & $0.5(0.5)$ & 0.5 \\
\hline
\end{tabular}

（）内の数值は、旧、新、次世代省エネについては省エネルギーハンドブックの基準值、次世代超につい ては文献 (5)の設定値を示す。

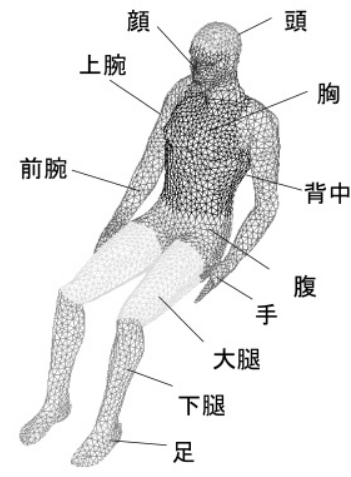

図 2 人体モデル

表 2 境界条件

\begin{tabular}{|c|c|c|c|c|c|c|c|}
\hline \multirow{9}{*}{$\begin{array}{l}\text { 流体計算 } \\
\text { ルーチン }\end{array}$} & \multirow{2}{*}{\multicolumn{2}{|c|}{ 流 出 入 口 }} & \multicolumn{2}{|c|}{ エアコン } & \multirow{2}{*}{ 給気口 } & \multirow{2}{*}{ 給気シリンダー } & \multirow{2}{*}{ 排気口 } \\
\hline & & & 吹出し口 & 吸込み口 & & & \\
\hline & \multirow{4}{*}{ 流入境界条件 } & 速 度 $[\mathrm{m} / \mathrm{s}]$ & $\begin{array}{c}6.0 \\
\left(\text { 鉛直下方 } 30^{\circ}\right) \\
\end{array}$ & $-0.49 ※$ & $\begin{array}{l}\text { 上向き: } 0.84 \% \% \\
\text { 水平方向 }: 1.01\end{array}$ & $0.429 \% ※$ & $-0.865 ※ ※ \%$ \\
\hline & & 温 度 $\left[{ }^{\circ} \mathrm{C}\right]$ & $25.0 \sim 43.3^{*}$ & 一 & 5.5 & 5.5 & - \\
\hline & & 乱流強度 $[-]$ & 0.1 & - & 0.1 & 0.01 & - \\
\hline & & 乱れの長さスケール $[\mathrm{m}]$ & 0.055 & - & 0.01 & 0.0018 & - \\
\hline & \multicolumn{2}{|c|}{ 固 体 面 } & \multicolumn{2}{|c|}{ 人体モデル } & \multicolumn{3}{|c|}{ 壁体 } \\
\hline & \multirow{2}{*}{ 壁面境界条件 } & 速 度 & \multicolumn{5}{|c|}{ no-slip } \\
\hline & & 温 度 & \multicolumn{5}{|c|}{ 放射計算ルーチンによって求められる温度 } \\
\hline
\end{tabular}

\begin{tabular}{|c|c|c|c|c|}
\hline \multirow{4}{*}{$\begin{array}{l}\text { 放 射 計 算 } \\
\text { ルーチン }\end{array}$} & 固 体 面 & 人体モデル & 床暖房 & 壁 体 \\
\hline & 温 度 & $\begin{array}{l}\quad q=\frac{36.4-t_{c l}}{0.054+0.155 I_{c l}} \\
q: \text { 熱流束 }\left[\mathrm{W} / \mathrm{m}^{2}\right] 、 t_{c l}: \text { 着衣表面温 } \\
\text { 度 }\left[{ }^{\circ} \mathrm{C}\right] 、 I_{c l}: \text { 着衣の熱抵抗 }[\mathrm{c} 1 \mathrm{o}]\end{array}$ & $\begin{array}{l}\text { 床暖房パネル上面 } 23.7 \sim 41.3^{\circ} \mathrm{C} \% \\
\text { 床表面までの熱抵抗 } 0.15 \mathrm{~m}^{2} \mathrm{~K} / \mathrm{W}\end{array}$ & $\begin{array}{l}\text { 室内壁から外気 } \\
\text { までの熱抵抗 } \\
\text { 外気温は } 5.5^{\circ} \mathrm{C}\end{array}$ \\
\hline & 放射率 [- ] & 0.9 & \multicolumn{2}{|l|}{0.9} \\
\hline & 対流熱流束 & \multicolumn{3}{|c|}{ 流体計算ルーチンによって求められる対流熱流束 } \\
\hline
\end{tabular}

$※$ 各断熱レベルに対して、人体顕熱放熱量が $44.2 \mathrm{~W} / \mathrm{m}^{2}$ になるように調整

※※ 吹出し質量流量と吸込み質量流量を一致させるため、吸込み速度を吹出し温度ごとに修正を加えている

$※ ※ \%$ 換気回数 0.5 回 $/ \mathrm{h}$ の場合の值を示す

準、次世代超断熱仕様および壁体完全断熱を対象とした。各省エネ ルギー基準に対する建物部位ごとの熱貫流率と換気回数の設定值を 表 1 に示す。木造戸建住宅を対象とした。括弧内の数值は、旧、新、 次世代省エネルギー基準では省エネルギーハンドブックに記載され ている基準值、次世代超では文献(5)の設定值である。建物の熱損失 係数を基準值に一致させることを優先させたため、壁、床の熱貫流 率は省エネルギーハンドブックに記載されている基準值とは若干異 なる。建物の熱損失係数は建物全体を対象とした断熱性能を表す指 標であるが、本研究では住宅の居間のみを切り取ったモデルを考え、 居間の北壁、東壁および天井は、暖房された隣室に接していると仮 定して断熱として扱い、熱損失係数については建物全体の值をその まま用いた。カーテンの熱抵抗は $0.01 \mathrm{~m}^{2} \mathrm{~K} / \mathrm{W}$ とした。

床暖房部の構成を図 1(b)に示寸。床暖房パネル(幅 $2.38 \mathrm{~m} \times$ 奥行 $3.29 \mathrm{~m}$ )を 2 枚設置し、床暖房敷設率は内寸法基準で $78 \%$ になる注 2 )。 温水パネル上面から床表面までの熱抵抗を $0.15 \mathrm{~m}^{2} \mathrm{~K} / \mathrm{W}$ とし、温水 パネル上面から上方を解析対象とした。エアコンはその下端が南壁 の床上 $2.1 \mathrm{~m}$ にくるように設置した。鉛直下方から $30^{\circ}$ の向きに速 度 $6.0 \mathrm{~m} / \mathrm{s}$ で温風を吹出すものとした（図 $1(\mathrm{c})$ ) 注 3 )。有効吹出し口 寸法は $0.55 \mathrm{~m} \times 0.03 \mathrm{~m}$ とした。固体面メッシュ数は約 22,000 、空間
セル数は約 260,000 である。

\section{2 人体モデル}

図 2 に示寸椅座位の男性精密人体形状モデルを用いた。身長 $1.72 \mathrm{~m}$ 、表面積 $1.86 \mathrm{~m}^{2}$ の体格とした。人体モデルは南壁から $1.9 \mathrm{~m}$ 、 東壁から $1.6 \mathrm{~m}$ の位置（熋部の中心）に設置し、メッシュ作成の都 合上足裏は床から $20 \mathrm{~mm}$ 浮いた状態とした注 ${ }^{4}$ )。人体各部の着衣量 は冬季の標準的な室内着に相当する 1clo とした。ただし、足は 0.3 clo、頭は $2 \mathrm{clo}$ 、顔・首・手は $0 \mathrm{clo}$ とした。人体表面のメッシュ数 は約 9000 であり、表面から厚さ $1 \mathrm{~mm}$ のプリズム形状の境界層メ ッシュを倍率 1.1 で 3 層押し出した。壁座標 $\mathrm{y}^{+}$はおおむお称 1 以下で ある。壁体およびカーテンの表面からは、厚さ $3 \mathrm{~mm}$ の境界層メッ シュを倍率 1.1 で 3 層押し出した。

\section{3. 解析方法および境界条件}

熱的中立状態にある人体の放熱量と皮膚温を、刘流・放射連成シミ ユレーションによって解析する。対流解析は、SIMPLE 法と二次精 度の差分スキーム MARS (単調移流再構成スキーム)を用い, Lien 等 の低レイノルズ数型乱流モデル20)を採用した。放射解析は、対称化演 算によって精度を向上させた Monte Carlo 法 21 をを用いた。人体から 
の放熱量は、サーマルマネキンの コンフォート制御に用いられてい る制御方式である熱的中立式 14)を 着衣の熱抵抗を勘案できるよう拡 張した式（1）を用いた。

$$
q=\frac{36.4-t_{c l}}{0.054+0.155 I_{c l}}
$$

ただし、着衣の外表面積が体表面 積に比べて増加することによる着 衣熱抵抗の減少は考慮していない。 ここで、 $q$ は顕熱熱流束 $\left[\mathrm{W} / \mathrm{m}^{2}\right] 、 t_{c l}$ は着衣表面温度 $\left[{ }^{\circ} \mathrm{C}\right] 、 I_{c l}$ は着衣の 熱抵抗 $[\mathrm{clo}]$ である。 $I_{c l}=0$ のとき、 $t_{c l}$ は皮膚温 $t_{s k}$ に等しい。

表 2 に主な境界条件をまとめて 示す。各断熱レベルに対して椅座 位の人体モデルの顕熱熱流束の平 均值が代謝量 $1.1 \mathrm{met}$ 時の熱的中 立状態に相当する值 $\left(44.2 \mathrm{~W} / \mathrm{m}^{2}\right)$ になるように、床暖房では温水パ ネル上面温度を $23.7 \sim 41.3^{\circ} \mathrm{C}$ に、 エアコンでは吹出し温度を 25.0 $\sim 43.3^{\circ} \mathrm{C}$ に調整することにより暖 房システムから室内への投入熱量 を与えた。なお、人体からの顕熱 熱流束が等しいことは、等価温度 が等しいことと同義である。室内 壁表面から外気までの熱抵抗は、室 内における熱伝達抵抗を $0.13 \mathrm{~m}^{2} \mathrm{~K} / \mathrm{W}$ とし、表 1 に示寸熱貫 流率の逆数からこの值を差し引い て求めた。

放射計算ルーチンにおいて求め られた人体および室内の各表面温 度分布を対流計算ルーチンにおい

て温度規定境界条件として設定して計算を行う。次に対流計算ルー チンにおいて求められる各表面の対流熱流束を放射計算ルーチンに おいて熱量保存則から表面温度分布を求める。これらのルーチンを 収束解が得られるまで繰り返す。

なお、本研究で用いたシミュレーション手法については、人工気 候室内におけるサーマルマネキン実験結果と比較寸ることにより妥 当性を確認している ${ }^{22-25)}$ 。

\section{4. 解析結果}

\section{1 壁体表面温度分布}

次世代省エネルギー基準の場合について壁体および人体の表面温

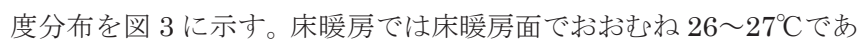
る。壁面はおおむ利 $21 \sim 22^{\circ} \mathrm{C}$ に分布している。西壁の上部の給気口 周囲では外気が進入するため $16^{\circ} \mathrm{C}$ 以下と温度が低い。カーテン表面

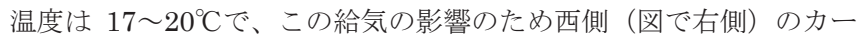

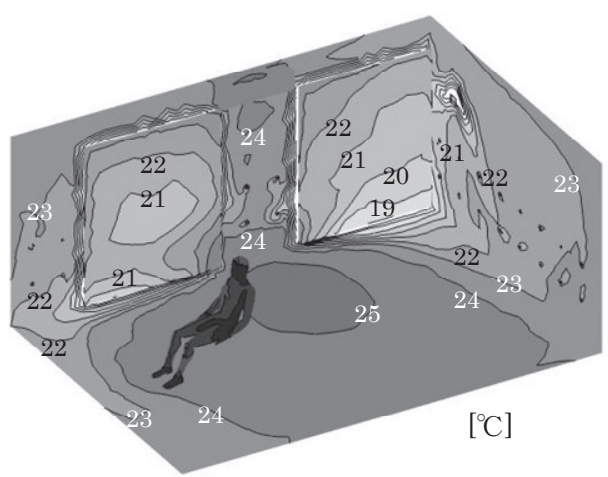

(b) エアコン

図 3 壁体および人体表面温度分布（次世代省エネルギー基準）

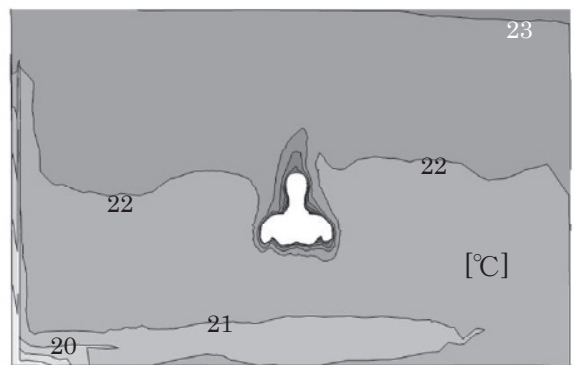

(a) 床暖房

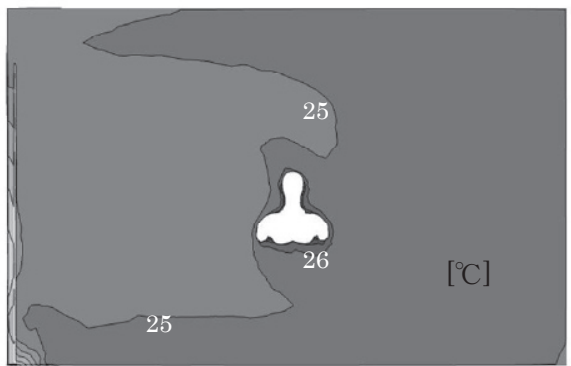

(b) エアコン
図 4 空気温度分布（次世代省エネルギー基準）

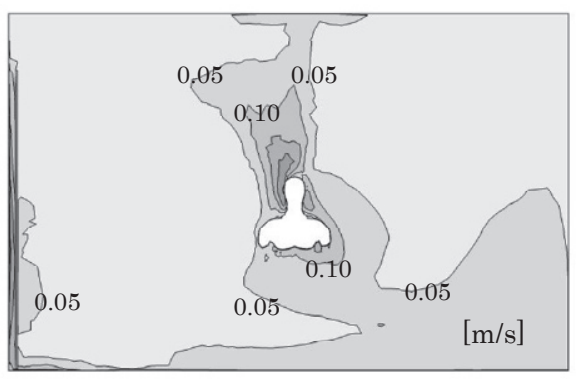

(a) 床暖房

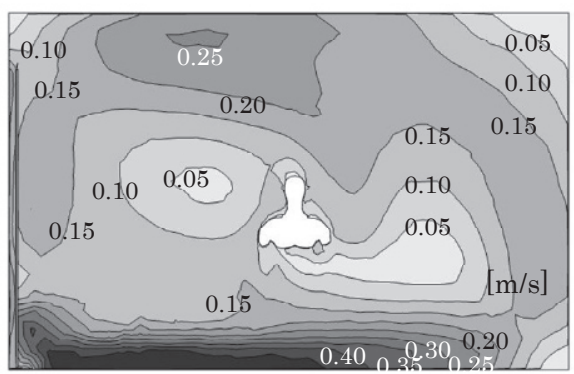

(b) エアコン
図 5 スカラー風速分布（次世代省エネルギー基準）

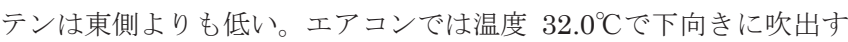
気流が衝突する床表面で $25 \sim 26^{\circ} \mathrm{C}$ と最も高く、その周囲に向かって 次第に低下寸る同心円状の温度分布となっている。壁面は $21 \sim 24^{\circ} \mathrm{C}$ に分布している。エアコン下方の壁温が高いのはエアコンの吹出し 気流のためである。西壁の上部の給気口周囲では外気が進入するた め $16^{\circ} \mathrm{C}$ 以下と温度が低い。この給気の影響のため、西側のカーテン 表面温度が東側よりも低いのは床暖房と同様である。

次世代省エネルギー基準より断熱性能が高い次世代超、壁体完全 断熱では室内各面の温度は均一に近づき、断熱性が低い新省エネル ギー基準、旧省エネルギー基準では、面ごとの温度の差は拡大寸る 傾向がある(図は省略)。

\section{2 室温および風速分布}

次世代省エネルギー基準の場合について人体モデルを含む鉛直断 面内の空気温度および風速分布を図 $4 、 5$ に示す。床暖房では、空 気温度は床近傍を除いて $20 \sim 23^{\circ} \mathrm{C}$ で比較的一様な分布である。人体 
周囲には、特に頭上に人体の 発熱に伴うプリュームが明瞭 に現れている。エアコンでは、 室温は $24 \sim 26^{\circ} \mathrm{C}$ の分布とな っている。エアコンからの吹 出し気流は図 3(b)から明らか なように床に到達しており、 床近傍を除いてほぼ一様な温 度分布を形成している。人体 周囲には、人体の発熱に伴う プリュームはほとんど見られ ない。

図 5 に示すように、床暖房 の場合は、 $0.1 \mathrm{~m} / \mathrm{s}$ 以下の静穏 な気流場である。エアコンで はエアコンの下向き吹出し気 流が部屋全体を攪汼している ため部屋中央で $0.1 \sim 0.2 \mathrm{~m} / \mathrm{s}$ 、 人体モデル近傍の床付近で最 大 $0.4 \mathrm{~m} / \mathrm{s}$ に達している。床 暖房に比べて風速が大きいた めにドラフトが増加するとと もに足部における対流熱流束 の増加による局部不快感が増 大寸る懸念がある。

\section{3 皮膚温分布}

次世代省エネルギー基準の場合について皮膚温分布を図 6 に示寸。 エアコンの場合の右足は床暖房の場合に比べて $0.5^{\circ} \mathrm{C}$ 低い。これは

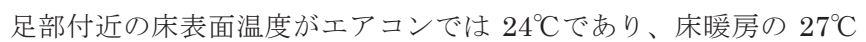
と比べて低いことが原因として挙げられる。右足が左足よりも皮膚 温が低いのは、温度の低い空部（カーテン）に向き合っているため である。エアコンの場合の手は床暖房と比べて $0.5 \sim 0.6^{\circ} \mathrm{C}$ 低い。こ れは床表面温度の相違に加えて、エアコンでは人体周囲の風速が大 きいために対流熱伝達が促進されるためと考えられる。上半身では、 エアコンは床暖房よりも $0.1{ }^{\circ} \mathrm{C}$ 程度高い。

\section{4 上下空気温度分布}

図 7 に上下空気温度分布を、床暖房は実線でエアコンは破線で示 す (北壁から $0.4 \mathrm{~m}$ 、東壁から $1 \mathrm{~m}$ の位置注 $\left.{ }^{5}\right)$ )。床表面温度は建物の 断熱性が低いほど、エアコンでは低く、床暖房では暖房出力を増加 させるため高くなる。床暖房では、空面からのコールドドラフトと 南壁と西壁の下部に設けたシリンダーから流入する外気のため、床 表面温度から急激に低下した後天井方向に向けて緩やかに上昇する 温度勾配が形成される。エアコンでは、建物の断熱性が低いほど床 付近で低く天井付近で高い大きな上下温度分布が形成されるとする 経験則と異なり、床近傍を除くと一様に近い分布である。これは、 本解析で用いたエアコンの吹出し速度が $6 \mathrm{~m} / \mathrm{s}$ と大きいため吹出し 気流の影響が広範囲に及ぶためである。断熱性能が向上するに従い、 床暖房とエアコンの空気温度の差は小さくなる。壁体完全断熱でエ アコン吹出し速度が $6 \mathrm{~m} / \mathrm{s}$ の場合は、温度 $24.6^{\circ} \mathrm{C}$ の一様な分布にな

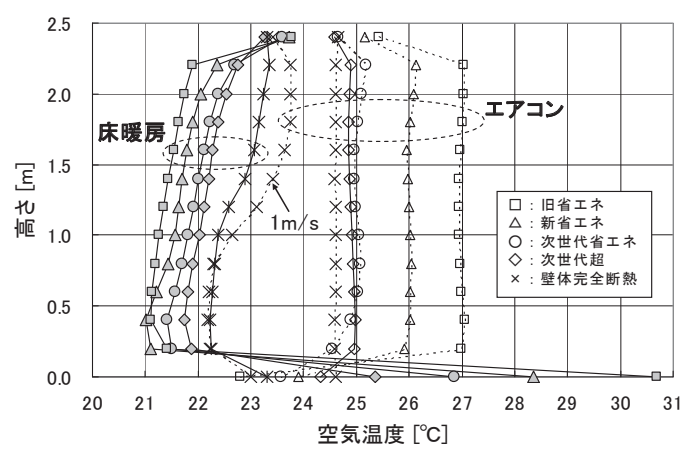

図 7 上下空気温度分布

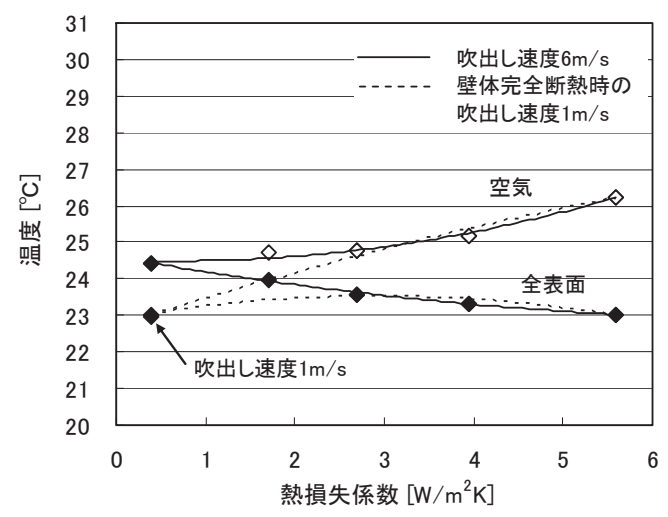

(b) エアコン

図 8 熱損失係数と室内温度の関係

る。断熱性能の向上に伴ってエアコンの吹出し速度を低下させるの が合理的と考えられるので、壁体完全断熱のケースについて吹出し 速度 $1 \mathrm{~m} / \mathrm{s}$ とした解析も行った。吹出し速度 $1 \mathrm{~m} / \mathrm{s}$ の場合、床暖房と エアコンの空気温度はほぼ一致する

\section{5 熱損失係数と室内温度}

図 8(a), (b)に熱損失係数と室内温度の関係を示す。床暖房では、熱 損失係数が大きい場合（低断熱）には床暖房表面温度が高く床暖房以 外の室内表面温度が低いが、全表面の平均温度注 6) は断熱性能に係わ らずほぼ一定である。室内空気の平均温度注 7) は断熱性が向上するに 従い高くなる。これらの温度は壁体完全断熱のとき約 $23^{\circ} \mathrm{C}$ とる。

エアコンでは、熱損失係数が大きい場合、平均空気温度が高く全 表面の平均温度が低く両者の差が大きいが、断熱性能を向上させる に従い小さくなり、壁体完全断熱のとき吹出し速度 $6 \mathrm{~m} / \mathrm{s}$ では

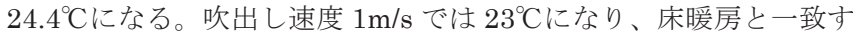
る。このとき、空気温度と室内表面温度が等しく、室内の風速がほ ぼ $0 \mathrm{~m} / \mathrm{s}$ であるため、この解析条件における等価温度は $23^{\circ} \mathrm{C}$ とな すことができる。

\section{6 暖房投入熱量}

人体顕熱熱流束が $44.2 \mathrm{~W} / \mathrm{m}^{2}$ となるときの、床暖房およびエアコン の暖房投入熱量を建物モデルの断熱性能ごとに表 3 に示す。床暖房 では温水パネルに供給される熱量のうち、温水パネルから上方に向 かって室内に放熱されるものを室内投入熱量、下方に向から放熱量 を床下損失としている。床下損失は式(2)によって見積もった。

$$
Q_{p}=A\left(t_{p}-t_{\text {out }}\right) / R_{p}
$$


ここで、 $A$ は温水パネル面積 $\left[\mathrm{m}^{2}\right] 、 R_{p}$ は温水パネルから床下空気ま での熱抵抗 $\left[\mathrm{m}^{2} \mathrm{~K} / \mathrm{W}\right] 、 t_{p}$ はパネル表面温度 $\left[{ }^{\circ} \mathrm{C}\right] 、 t_{\text {out }}$ は床下空気温度 $\left[{ }^{\circ} \mathrm{C}\right]$ である。次世代省エネルギー基準で上面放熱率を $0.83^{26)}$ として、

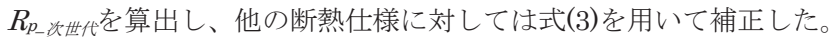

$$
R_{p}=\frac{\text { 次世代省エネ基準の熱損失係数 }}{\text { 任意の断熱性能の熱損失係数 }} \times R_{p_{-} \text {次世代 }}
$$

エアコンでは、吹出し空気と吸込み空気の顕熱の差に相当する熱 量が室内投入熱量であり、これに人体放熱量を加えた熱量が室内へ の全入熱量となる。床暖房で は、室内投入熱量に人体放熱 量を加えたものを室内放熱量、 さらに床下損失を加えたもの を全入熱量とした注8)。括弧内 の数字は、エアコンを 1 とし たときの比率を表している。

図 9 に断熱性能と投入熱量 の関係を示す。断熱性能の向 上に伴って、室内投入熱量お よび床下損失が大幅に減少し ていく様子を示している。壁 体完全断熱の場合、全入熱量 は換気負荷と一致する。

図 10 は床暖房のエアコン に対する全入熱量の比および 室内投入熱量の比と熱損失係 数の関係を示したものである。 温水パネル下部の断熱性を壁 体の断熱性能に合わせて向上 させる場合、全入熱量比はい ずれの熱損失係数においても 1 を下回っている。実線は熱 損失係数に係わらずエアコン 吹出し速度を $6 \mathrm{~m} / \mathrm{s}$ 一定とし た場合である。熱損失係数が 小さくなる（断熱性が向上）

に従いエアコンの吹出し温度 が低下するため人体周りの対流熱流束が増加することとなり、全入 熱量比、室内投入熱量比とも熱損失係数 $2 \mathrm{~W} / \mathrm{m}^{2} \mathrm{~K}$ 付近でピークを持 つ上に凸の曲線となった。壁体完全断熱の場合のエアコン吹出し速 度を $1 \mathrm{~m} / \mathrm{s}$ とした場合（室内投入熱量は $55 \mathrm{~W}$ ）の解析結果も図 10 に示す。破線は、旧、新、および次世代省エネルギー基準の全入熱 量比とこの点をスムーズに結んだものであり、全入熱量の比は、熱 損失係数が小さくなるに従い 1 に近づくことがわかる。

図 8 の熱損失係数と室内温度の関係を見ると、人体からの顕熱放 熱量を $44.2 \mathrm{~W} / \mathrm{m}^{2}$ に保つ場合、たとえば旧省エネルギー基準では、 壁体貫流熱量に関係する全表面平均温度は、床暖房とエアコンでほ ぼ等しく、換気損失熱量に関係する平均空気温度は床暖房で $21.5^{\circ} \mathrm{C}$ 、 エアコンで $26.2^{\circ} \mathrm{C}$ となり、アコンの方が高い。この結果全入熱量 比は 0.81 となった。これらの温度の差は、熱損失係数が小さくなる に従い縮小し、新省エネルギー基準で 0.89、次世代省エネルギー基
準で 0.92 と予測された。壁体完全断熱の場合、床暖房と吹出し速度 $1.0 \mathrm{~m} / \mathrm{s}$ のエアコンで比べるといずれの温度も約 $23^{\circ} \mathrm{C}$ とり (図 8)、 全入熱量比はほぼ 1 になる。

床暖房の場合、温水パネルより下部の断熱性能により床下損失熱 量が変わるので、床暖房の床下損失を含めない室内投入熱量の比を エアコンを 1 として示すと、旧省エネルギー基準で 0.62 、新省エネ ルギー基準で 0.71 、次世代省エネルギー基準で 0.75 となる。なお、 壁体完全断熱の場合、床暖房の床下損失がゼロになるので室内投入

表 3 断熱性能と暖房投入熱量 ([W])

\begin{tabular}{|c|c|c|c|c|c|c|c|c|c|c|}
\hline 断熱性能 & \multicolumn{2}{|c|}{ 旧省エネ } & \multicolumn{2}{|c|}{ 新省エネ } & \multicolumn{2}{c|}{ 次世代省エネ } & \multicolumn{2}{|c|}{ 次世代超 } & \multicolumn{2}{|c|}{ 壁体完全断熱 } \\
\hline 暖房方式 & 床暖房 & エアコン & 床暖房 & エアコン & 床暖房 & エアコン & 床暖房 & エアコン & 床暖房 & エアコン \\
\hline \hline 室内 & 1167 & 1890 & 853 & 1199 & 607 & 806 & 383 & 505 & 54 & 75 \\
投入熱量 & $(0.62)$ & $(1)$ & $(0.71)$ & $(1)$ & $(0.75)$ & $(1)$ & $(0.76)$ & $(1)$ & $(0.72)$ & $(1)$ \\
\hline 床下損失 & 343 & - & 207 & - & 124 & - & 76 & - & 0 & - \\
\hline 人体放熱量 & 84 & 84 & 84 & 84 & 84 & 84 & 84 & 84 & 84 & 84 \\
\hline 室内放熱量 & 1251 & 1974 & 937 & 1283 & 691 & 890 & 467 & 589 & 138 & 159 \\
& $(0.63)$ & $(1)$ & $(0.73)$ & $(1)$ & $(0.78)$ & $(1)$ & $(0.79)$ & $(1)$ & $(0.87)$ & $(1)$ \\
\hline \multirow{2}{*}{ 全入熱量 } & 1593 & 1974 & 1144 & 1283 & 815 & 890 & 542 & 589 & 138 & 159 \\
& $(0.81)$ & $(1)$ & $(0.89)$ & $(1)$ & $(0.92)$ & $(1)$ & $(0.92)$ & $(1)$ & $(0.87)$ & $(1)$ \\
\hline
\end{tabular}

注1）本表では、温水パネルに供給される熱量のうち、温水パネルから上方に向かうものを室内投入熱量、下方に向 からものを床下損失としている。 床下損失に相当寸る損失が室内投入熱量に含まれている。

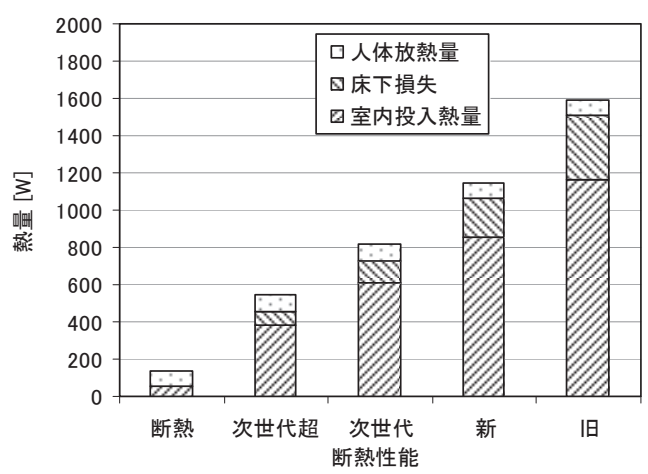

(a) 床暖房

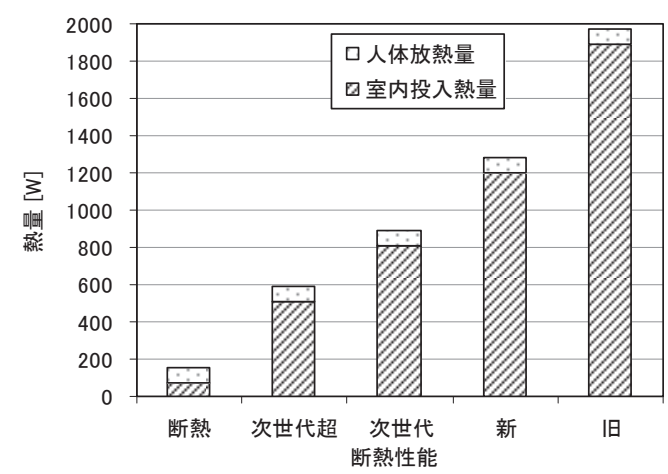

(b) エアコン
図 9 断熱性能と投入熱量の関係

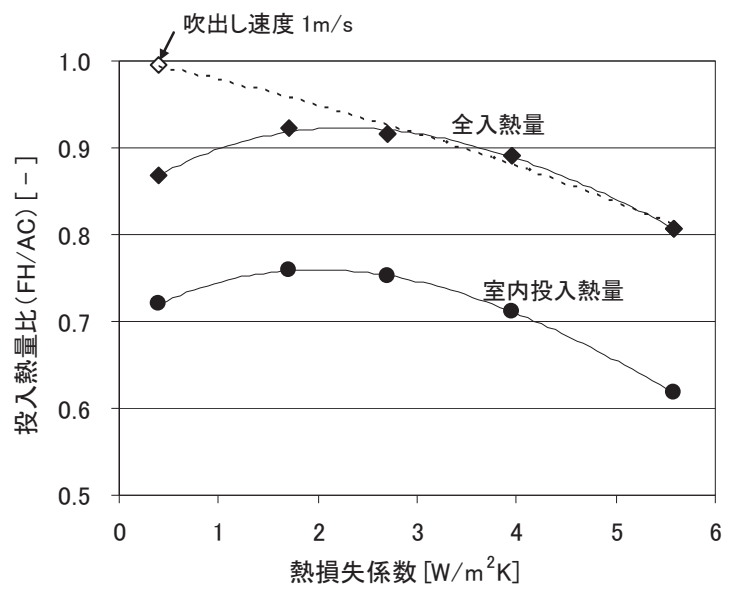

図 10 熱損失係数と投入熱量比 ( $\mathrm{FH}$ (床暖房)/ $\mathrm{AC}$ (エアコン) 
熱量比も 1 に近づくことになる。

\section{5.まとめ}

建物の断熱性能と暖房システムによって、暖房投入熱量がどのよ うに変わるのかを、人体の顕熱放熱量を一定、すなわち等価温度を 一定とした条件下で対流・放射連成解析によって詳細に調べた。断 熱性能は旧・新・次世代の 3 省エネルギー基準と次世代省エネルギ 一基準を上回る断熱性能の次世代超、および究極の断熱性能である 壁体完全断熱の 5 つのレベルとし、暖房システムは代表的な放射方 式である床暖房、温風方式であるエアコンとした。

建物の断熱性能の向上に伴い、床暖房、エアコンともに暖房投入 熱量は顕著に減少する。建物の断熱性能と全投入熱量の関係を床暖 房とエアコンで比較すると、床暖房の温水パネル下部の断熱性能を 壁体の断熱性能に合わせて向上させる場合には、吹出し風速 $6 \mathrm{~m} / \mathrm{s}$ のエアコンの全入熱量を 1 とした場合、床暖房では旧省エネルギー 基準で 0.81 、新省エネルギー基準で 0.89 、次世代省エネルギー基準 で 0.92 となり、断熱性能が向上するほど（熱損失係数が小さくなる ほど）床暖房とエアコンの全入熱量の差が小さくなる傾向が見られ た。壁体を完全断熱とし、エアコンの吹出し風速を $1 \mathrm{~m} / \mathrm{s}$ とした場 合には、床暖房とエアコンの差はほとんどなかった。室内投入熱量 は吹出し風速 $6 \mathrm{~m} / \mathrm{s}$ のエアコンを 1 とした場合、床暖房では旧省エ ネルギー基準で 0.62 、新省エネルギー基準で 0.71 、次世代省エネル ギー基準で 0.75 と予測された。

本研究では、床暖房とエアコンの快適性や局部温冷感の相違につ いては評価の対象としなかった。今後、快適性を予測する上でより 適切と考えられる人体血流モデルを用いて異なる暖房方式間の快適 性の違いに関して研究を進めていく予定である。

\section{謝辞}

本研究は（財）ベターリビング「快適性を考慮した異なる暖房方式 のエネルギー評価手法に関する研究委員会」(委員長 鎌田元康 神奈 川大学工学部教授）の活動の一部を発展させたものである。委員各位 に感謝の意を表す。

\section{参考文献}

1）板垣、大森、田辺：対流・放射連成シミュレーションによる室内温熱環 境の総合評価（その 8) 建物の断熱性能・暖房システムと暖房エネルギ 一の関係、日本建築学会大会学術講演梗概集D-2、pp. 369-370、2008.9

2) 須藤、小峯、田辺、倉㴊、吉田、斎藤 : 高気密 - 高断熱居室と標準居室 における各種暖房の温熱環境・エネルギー消費量に関する研究、空気調 和・衛生工学会学術講演会講演論文集、pp. 789-792、1992.10

3）快適な温熱環境のメカニズム、空気調和・衛生工学会、pp. 184-188、2006.3

4）堀、伊藤、須永、室 : 不均一熱環境における熱的快適性の評価に関する 研究一床面温度が熱的快適性に及ぼす影響と局部温冷感による熱的快適 性予測について、日本建築学会計画系論文集、第 501 号、pp. 37-44、 1997. 11

5）住宅事業建築主の判断の基準におけるエネルギー消費量計算方法の解説、 建築環境・省エネルギー機構、2009.3

6) 大森: サーマルマネキンを用いた最新の研究事例、空気調和・衛生工学、 第 84 巻、第 2 号、pp. 43-49、2010. 2

7) ISO 7730: Moderate thermal environments - Determination of the PMC and PPD indices and specification of the conditions for thermal comfort, 1994

8) ASHRAE STANDARD 55-2004: Thermal Environmental Conditions for Human Occupancy
9）大森、田辺：対流・放射連成シミュレーションによる室内温熱環境の総 合評価（その 1) 実験值との比較による総合評価法の検証、日本建築学会 大会学術講演梗概集D-2、pp. 169-170、2005.9

10) 大森、田辺：対流・放射連成解析による住戸内温熱環境の快適性・エネ ルギー消費量総合評価（その1）異なる住宅断熱性能における床暖房・温 風暖房の解析、空気調和・衛生工学会大会学術講演論文集、pp. 865-868、 2005.8

11）田澤、上野、坂本、瓦口：室内温熱環境と省エネルギーの評価を目的と した住宅用暖房機器の人工気候室性能試験、日本建築学会技術報告集、 第 16 巻、第 32 号、pp. 227-232、2010.2

12）坂口、赤林、長谷川、浅間：住宅を対象とした床暖房時と温風暖房時の 熱収支に関する研究、日本建築学会環境系論文集、第 628 号、pp. 735-742、 2008.6

13) ISO 14505-2: Ergonomics of the thermal environment - Evaluation of thermal environments in vehicles, Part2 Determination of equivalent temperature, 2006.12

14) S. Tanabe, E. Arens, F. Bauman, H. Zhang and T. Madsen: Evaluating Thermal Environments by Using a Thermal Manikin with Controlled Skin Surface Temperature, ASHRAE Transactions 100 (1), pp.39-48, 1994

15）稲垣、鍵屋、松前他：快適性を考慮した異なる暖房方式のエネルギー評 価手法に関する研究、その 2 人工気候室内実験住宅の概要、日本建築学 会大会学術講演梗概集 D-2、pp. 437-438、2007.8

16) 松前、鍵屋、稲垣他：快適性を考慮した異なる暖房方式のエネルギー評 価手法に関する研究、その 3 被験者実験による床暖房とエアコンの比較、 日本建築学会大会学術講演梗概集D-2、pp. 439-440、2007.8

17) 大島、倉㴊、岩本他：異なる暖房方式を採用した居室の温熱環境評価に 関する研究、その 1 床暖房・エアコンにより形成される居室の温熱環境 の把握、日本建築学会大会学術講演梗概集D-2、pp. 31-32、2007.8

18）田辺、鍵屋、松前他：サーマルマネキンによる各種暖房方式の快適性と 投入熱量の評価、空気調和・衛生工学会大会学術講演論文集、pp. 473-476、 2008.8

19) 清水、倉㴊、岩本他 : 暖房室内の温熱環境評価に関する研究、第 3 報 床 暖房・エアコンにより形成される居室の温熱環境と投入熱量の把握、空 気調和・衛生工学会大会学術講演論文集、pp. 477-480、2008.8

20) F.S. Lien, W.L. Chen and M.A. Leschziner: Low-Reynolds-Number Eddy-Viscosity Modelling Based on Non-Linear Stress-Strain/Vorticity Relations, Proc. 3rd Symposium On Engineering Turbulence Modelling and Measurements, pp.1-10, 1996

21) 大森、梁、加藤、村上 : 大規模 - 複雑形状に対応する対流 - 放射連成 ミュレーション用放射伝熱解析法の開発、第 2 報一対流・放射連成解析 による実人体周りの温熱環境の解析、空気調和・衛生工学会論文集、No. 90、 pp. 93-102、2003. 7

22) 大森、田辺：対流・放射連成シミュレーションによる室内温熱環境の総 合評価（その 4) 人工気候室におけるサーマルマネキン実験に対応する モデルの作成、日本建築学会大会学術講演梗概集D-2、pp. 25-26、2007.8

23) 板垣、大森、田辺：対流・放射連成シミュレーションによる室内温熱環 境の総合評価（その 5) 解析結果とサーマルマネキン実験結果との比較、 日本建築学会大会学術講演梗概集D-2、pp.27-28、2007.8

24) 板垣、大森、田辺：対流・放射連成シミュレーションによる室内温熱環 境の総合評価（その 7 ）人体姿勢および暖房システムと人体放熱量の関 係、日本建築学会大会学術講演梗概集 D-2、pp.367-368、2008.9

25) T. Omori and S. Tanabe: Coupled Simulation of ConvectionRadiation-Thermoregulation for Predicting Human Thermal Sensation, Proceedings of Roomvent 2007, 2007

26) 武部、三村、中川、鍵屋、松前、田辺：サーマルマネキンによる床暖房 の快適性評価と投入熱量（その 2 ）実生活を考慮した快適性評価と投入 熱量、日本建築学会大会学術講演梗概集D-2、pp.69-70、2008.9

注

注1）本研究で用いた居間モデルは、人工気候室に設置された建物モデルの居 間をできるだけ忠実に数值モデル化したものである。この建物モデルを 用いて、異なる暖房方式間の温熱環境や室内投入熱量に関する実験が別 途実施・報告されている 15-19)

注2）壁芯寸法基準では 70\%に相当する。

注3）エアコンからの吹出し速度については、実験に基づく推定值である。な 
お、エアコンの吹出し速度が小さい場合は上下温度差が大きく形成され る。一方、大きい場合は上下温度差は小さくなるものの、人体表面にお ける対流熱伝達が促進される。建物の断熱性能が向上寸れば吹出し速 度・温度ともに小さくするのが合理的と考えられるので、壁体完全断熱 のケースについて吹出し速度 $1 \mathrm{~m} / \mathrm{s}$ とした解析も実施して、吹出し速度 の影響について調べた。

注4）足裏と床との間の $20 \mathrm{~mm}$ の空間では、対流と放射による熱交換があるも のの、接触熱伝導は無視される。

注5）エアコンの吹出し気流の直接的な影響と人体モデルの影響が小さい場所と して北壁から $0.4 \mathrm{~m} 、$ 東壁から $1.0 \mathrm{~m}$ の位置を選定した。

注6）全表面の平均温度は、人体を取り囲む表面の面積重み付け平均温度である。 従って、カーテンにより隠された空面の温度は含まれない。

注7）平均空気温度は、セル体積で重み付けした平均値である。

注8）エアコンの場合：室内投入熱量 + 人体放熱量 $=$ 室内放熱量 $=$ 全入熱量、 床暖房の場合 : 室内投入熱量 + 人体放熱量 $=$ 室内放熱量、室内放熱量 + 床下損失 $=$ 全入熱量

（2010年 3 月10日原稿受理，2010年11月26日採用決定） 